\title{
The Necessity and Features of Local Government Reform in Albania
}

\author{
Doct. Arben Hysi
}

\author{
University "Ismail Qemali" Vlore, Business Department
}

Email: hysiarben@yahoo.com

Doi:10.5901/ajis.2014.v3n3p71

\begin{abstract}
"Construction of state systems in different countries, is consistent with a number of social and economic factors, The combination of them adapted to the internal environment and external determines the level of welfare of the respective communities. Horizontal separation of powers is given an importance local government: first in bringing quality services and timely; secondly in the definition and implementation of appropriate policies in the economic development of the respective community. Various social problems and poor work in local government services closer to the community makes its reorganization necessary, to increase the efficiency and quality of services. Reform of local government in developed countries and those in transition adapted to the specific conditions of the respective countries is a good experience for us to consider the reorganization process in Albania, to make this process in the most effective. The aim of this study is the focus behavior problems encountered in discussions about local government reform, the specifics of our country, as well as practical recommendations implemented in other countries, problems and practices.
\end{abstract}

Keywords: Government, Administration, Reform, Local, Community .

\section{Introduction}

Construction and operation of local government existed in ancient times and has been the basis of modern state building itself that exists today in all societies throughout the world. Even in Albania, it has always been a basic social and political development with a strong impact despite internal situations of external stabilization of the national state itself. The reason of this effect is the economic structuring of Albanian society, compared with other European countries which had the possibility of economic development of the capitalist order. Albania remained up later a feudal country, due to the late separation from the Turkish Empire. But the regional strong feeling reflected in the efforts to acquire power after separation from the Turkish Empire had a negative impact and became an obstacle to achieve a successful government up to the years 20 of $X X$ century.

In the construction of power in general and state in particular are based associations which are unions by rational interests accounts, in a sense, the basis of nation are communities which are communions based on having close natural connection to communities in a particular territory, characteristics of history, language, common customs. Precisely these communities are the basis of local government in Albania, taking into account the impact of their psychological characteristics, economic, social, in the construction of local government has a vital importance. For this reason in the Constitution ${ }^{1}$ of the Republic of Albania is specifically expressed the opinion taking of the population, to change the territories of local units. The aim is not only to protect the right of regional interests, but considering them as an asset for their traditions and history.

\section{Theoretic Debate}

The reform of local government, has been a problem of all European countries during the last century, which made an extreme reduction in the number of local units. But who was the cause of this transformation: first, the efficiency improve of governments local services, to have better quality service and in due time according to the needs of the respective communities; secondly, the change of economic and social conditions in these countries. Industrial development itself brought the natural concentration of population in urban areas. Development of infrastructure made it possible to reduce the implementation time delivery of quality services. Development of information technology made possible governance, transparency and citizen participation in governance respective communities. European countries used different ways, due to the nature of the national population characteristics and heritage of local government organization. In the countries

\footnotetext{
${ }^{1}$ Constitution of Albanian Republic, art. 108, sec 2, pg. 37
} 
where traditional feeling was stronger, as in the case of Germany and France, was used voluntary mergers and socialization. While in the Nordic countries were used the forced union way, but not in a single period, only Sweden has made this transformation process into four stages during the last century by adopting the construction of local power to the economical changing conditions. In general, Western European countries have an economy based on industry and a modern agriculture which have had a positive impact on the transformation of local government.

The purpose of local government reform is to increase the quality of services to citizens which can be achieved through two ways: primarily through increased service efficiency by reducing misuse of funds by the administration, secondly doing administrative-territorial reform, which automatically reduces duplication of services but also reduces administrative costs by reducing their joined number in a unit according to the case.

The countries of Eastern Europe after the fall of the communist system were involved all to the local government organization under the relevant national legislation. They relied on the principles of "European Card of Local SelfGovernment" for the necessary autonomy² to the local government, to perform its function by western concepts. The way that former communist countries followed is a good experience to be considered by the Albanian government for local government reform. The typical countries approximated to the surface and population with Albania is the case of the Republics of Moldova and Lithuania, for the

\section{Albanian Case}

Functioning and organization of local government in Albania has historically been a result of the political classes, under political systems that have led Albanian society during a time of a century. In general has dominated the practice centralization of this power from the center. Despite attempts by Vlora ${ }^{3}$ government that had as project the French model of organization of local government, it remains the only attempt over a century democratization of power in Albania until 1992.

In parallel with the efforts of King Zog for centralization of the country, significant changes were done even in administration. In early 1930 the local administrations were reorganized by providing a greater control over them. Law on Promulgation of municipalities was named "villager law" approved on April 11, 19294, communes of their own and communes composed by gathered villages, the firsts with over 2500 inhabitants and the seconds with united villages that were not far than $15 \mathrm{~km}$ with each other. The structure of local government was: prefecture, sub-prefecture, municipality for cities, municipalities for villages.

In the years after the Liberation of Albania, local government was concentrated, administration was organized on Law No. 684 dt. 11. 03. 1949, prefectures, sub-prefectures, districts (cities), towns (villages).

With the democratization of the Albanian society life, the local government was organized by "European Card of Local autonomy" and the Constitution of Albanian Republic by conducting elections ${ }^{5}$ for local leaders and representatives. By decision of KM No. 269 dt. 25. 06. 1992 was done the administrative reorganization, where the largest unit was the district consisting of municipalities and communes. Law6 No. 8652 approved by the Council of Ministers on 30. 102001 made changes reducing districts and reorganized counties as a second level of local units. In the practice of the District existence there are shortages in its competence which today raises question for this kind of organization. Among the projects presented ${ }^{7}$ I have the opinion about organizing regional levels and 6 units. A further reduction of the number of regions may require changes in its form of organization of local power because the regional expansion approaches the district power space. As an example we can bring the case of Moldova has 10 regions, compared to the number of 33 thousand area and population 4 million, that are similar to Albania.

Lithuania also has 12 regions, with 64 thousand surface and population 2.3 million inhabitants. What matters is to define the competencies that will have the region, which should be in accordance with the practices of the European community in order to take advantage of development funds.

The fragmentation of local government and its dysfunction, large numbers ${ }^{8}$ of under 2, 000 inhabitants in 70

\footnotetext{
2 European Card of Local Autonomy . followed way and the extended time of this process. Moldova has at the first level 225 local units , while Lithuania has a lower number 112 local units because of a smaller population

3 "State and right History in Albania "Tirane, 1994, pg. 71-73.

${ }^{4}$ KingZog and the effort for stability in Albania, Bernard J. Fischer, Botim Cabej2004, pg. 184

${ }^{5}$ Luis Favoreu, "droit Constitutional", Dallos, Paris1998, pg. 461

${ }^{6}$ Law about the Local Power organization and function. Official book no . 25, Aug, 2000.

7 Press "Shekulli" Trane, on 05. 05. 2014.

8 INSTAT, 2011
} 
municipalities, 94 municipality with at least 5000 inhabitants makes this reform necessary .

Mountainous terrain and lack of infrastructure, can hinder this process, but a financial support of the reformed units will be a success of Albanian politics and society. The short time of doing this process is a negative factor for a studied decision. It is worth to mention a quote in the Constitution ${ }^{9}$, to be taken in consideration the opinion of the population to change the territorial boundaries. This is an unclear problem that how the majority will operate without the consensus of opposition, to review the constitution.

\subsection{A study case}

To see what the population thinks I've taken as a reference a survey conducted in the district of Tepelena. Despite different political systems, which made the organization at different times of existence history and organization of local units, there is a common feature that the elements of local units are stored at nearly similar edges. To prove this we will consider the district of Tepelena: Communes of Qesarat and Krahes were together in the three periods mentioned above as well as those of Buzand Luftinje; Commune of Kurvelesh has always been of it's own. Tepelenaas a town had subprefectures in 1924 anda prefecture in 1953. All the units above-mentioned today must undergo a reform, but the ideas are different, the Government has a unit project with over 10, 000 inhabitants/unit. But should it be a condition to determine the local unit? The difficult terrain of $40 \%$ mountain and the infrastructure where all the villages have no paved roads are a negative factor for expanding the surface and distance of the center of the local units. A resident of the village Hallkomemaj actually spends for a service 300 new lek, with the reorganization will spend want 600 new leke, but even a double time from 2 hours to 3.5 hour round trip car.

Considering the cast of projects presented in public for territorial administrative division, according to "Web State" for 88 units is considered the nearest municipality, according to this Tepelena will have only 2 units : Municipality of Tepelene and that of Memaliaj. The municipality mayors are proposed by the majority in order to have cities in the first level . (Albania has had 36 cities ) .

Project: Considering the history of the organization of local government in the district of Tepelena, difficult terrain to have major functional areas, difficulties in infrastructure for communication and a complete service in time , I propose this division :

1. Union of Krahesand Qesarat communes because : a) both have a common regional and organizational history of the local power ; b)and lie in a functional Valleyconnected by the national road.

2. Union of Buz and Luftinje communes because : a)both have a common regional and organizational history of the local power ; b) and lie in a functional Valleyconnected by the national road.

3. Union of Memeliaj village and Memaliaj municipality because: a) the center of Memaliaj village is $400 \mathrm{~m}$ far from the center of Memaliaj municipality .

4. Union of Center commune with municipality of Tepelene because : a) Center commune is centered in city of Tepelene.

5. Union of Lopes, Center and Tepelene: a)asphalting of road Lopes-Tepelene will make possible service approach in time .

6. Cummune of Kurvelesh to stay by its own because : a) it has been by its own historically and a sub-prefecture in 1924; b)dysfunctional infrastructure and terrain make the necessary preservation of a separate unit.

\subsection{Methodology}

To confirm this project a survey was conducted in the district of Tepelene to prove what citizens thought. The questionnaire contained three variants: a) joined units by district-based model; b) model with the nearest municipality center; c) Localities model of the communes that matches to the above version.

Conclusions are as in the following table: The interviewed citizens are respectivelyas the municipalities with corresponding numbers in table 1. 1: Krahes, Qesarat, Buz, luftinje, Memaliaj village, Lopes, Kurvelesh, QenderTepelene, Memaliaj, Tepelene.

The sample is based on the number of voters in\%, which varies from 300 an up. All municipalities are according Cesusit under 3000 inhabitants .

\footnotetext{
${ }^{9}$ Constitution of Albanian Republic, art. 108, sec 2, pg. 37
} 
Table 1.1

\begin{tabular}{|c|c|c|c|c|c|c|c|c|c|c|}
\hline Communes & 1 & 2 & 3 & 4 & 5 & 6 & 7 & 8 & 9 & 10 \\
\hline $\mathrm{Yi}$ & 95 & 70 & 65 & 62 & 60 & 30 & 35 & 66 & 132 & 100 \\
\hline $\mathrm{Xi}$ & 82 & 58 & 51 & 49 & 47 & 24 & 29 & 46 & 126 & 131 \\
\hline
\end{tabular}

Variables: $Y i$ is dependent and is the no of citizens pro-reform, $\mathrm{Xi}$ is independent and is the no of citizens pro-project .

\subsection{Regression Analysis}

By processed data resulted that there is a connection between variables by regression analysis with this equation:

$Y_{i}=9.80+b_{1} * X_{i}$

Given the value of the determining Coefficient 0. 99096, we can say that it is within the range of 0 and 1and shows that there is an important connection between the variety variables, which is satisfactory.

The coefficient of correlation value is 0.980626 within the range -1 and +1 , indicating that the model selected is important as the variable. Student's test : if between variables exists a connection than $\beta 1$ can't be equal to 0 , this connection is estimated by checking assumptions.

Ho: $\beta 1=0$ Ha: $\beta 1 \neq 0$

By the regression table we can find out the value of $t$ factic, with a 2 scale loose, $t$ factic 20. 154 From the spread table, the student for the importance level 0.01 and loose scale $n-2$ we can find out t critic $t_{0.05}=3,355$. Since $t$ factic $>t$ critic , and P-value $=4.3 \mathrm{E}-08<0.01, \beta 1$ is not equal to 0, Ho is refused .

\section{Conclusion}

I think that this model could be a possible variant when economic and political support such as the problems in infrastructure, would hinder a model with the merger of more municipalities.

Pic 1. Map of Gjirokaster District

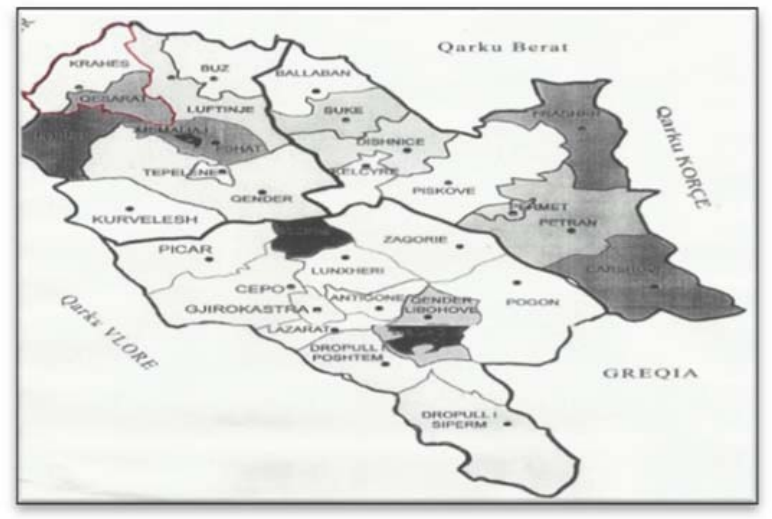




\section{References}

Dollery B. E. and L. Roboti (eds), 2008, The theory and Practice of Local Government Reform , pg. 23.

Swianiwicz P. (eds), 2002, Consolidation of Fragmentation, The size of Local Government in Central and Eastern Europe, Open Society Institute , Local Government and Public Service Reform initiative , Budapest pg. 31-4.

Olson M. 1969, "The Principle of Fiscal Equivalence: the Division of Responsibilities Among Different Levels of Government", American economic Review, pp49.

Daflon B. and T. Madies , 2009 , Decentralization: a Few Principles from the Theory of FiscalFederalism, Agency Francaise de Developpement, Notes and documents, No 42, May, Paris. Pg. 276-7

Luis, "Droit constitutional"Dallos, Paris 1998, pg. 461

"State and right history in Albania ", Tirane, 1994, pg. 71-73.

Bernard, J. Fisher "King Zogand his effort for stability in Albania", Botim "Cabej"2004, pg. 184

Victor Popa, Victor Mocanu" local Government in Moldavia.

\begin{tabular}{|c|c|c|c|c|c|c|c|}
\hline \multicolumn{2}{|c|}{ Summary Output } & & & & & & \\
\hline \multicolumn{2}{|c|}{ Regression Statistics } & & & & & & \\
\hline Multiple R & 0.990296 & & & & & & \\
\hline R Square & 0.980685 & & & & & & \\
\hline Adjusted R Square & 0.978271 & & & & & & \\
\hline Standard Error & 5. 80754 & & & & & & \\
\hline Observations & 10 & & & & & & \\
\hline \multicolumn{8}{|l|}{ ANOVA } \\
\hline & $d f$ & SS & $M S$ & $F$ & Significance $F$ & & \\
\hline Regression & 1 & 13699.78 & 13699.78 & 406.19 & 3. $84 \mathrm{E}-08$ & & \\
\hline Residual & 8 & 269. 8201 & 33. 72752 & & & & \\
\hline \multirow[t]{2}{*}{ Total } & 9 & 13969.6 & & & & & \\
\hline & Coefficients & Standard Error & t Stat & $P$-value & Lower 95\% Upper 95\% & Lower $95.0 \%$ & Upper $95.0 \%$ \\
\hline Intercept & 9.803324 & 3.79778 & 2.58133 & 0.032549 & $1.045628 \quad 18.56102$ & 1.045628 & 18.56102 \\
\hline $\mathrm{xi}=$ popullata pro $(000)$ & 1. 040321 & 0.051618 & 20. 15416 & 3. $84 \mathrm{E}-08$ & $0.921289 \quad 1.159353$ & 0.921289 & 1. 159353 \\
\hline
\end{tabular}

